\title{
A felnőtt lakosság dohányzási szokásai Nyíregyházán
}

\author{
Smoking habits among adult population in Nyíregyháza
}

Szerzők: $\quad$ Rákóczi Ildikóa $\bowtie$, Sárváry Attila ${ }^{b}$, Gyulai Anikóa ${ }^{a}$, Takács Péterc ${ }^{c}$, Jávorné Erdei Renáta ${ }^{a}$ a: Debreceni Egyetem, Egészségügyi Kar, Egészségtudományi Intézet, Védőnői Módszertani és Népegészségtani Tanszék, b: Debreceni Egyetem, Egészségügyi Kar, Egészségtudományi Intézet, Ápolástudományi Tanszék, c: Debreceni Egyetem, Egészségügyi Kar, Egészségtudományi Intézet, Egészségügyi Informatikai Tanszék

Beküldve: $\quad$ 2019. 09. 17.

doi:

10.24365/ef.v60i5.522

\begin{abstract}
Összefoglaló:
Bevezetés: Világmértékben a dohányzás évente közel 6 millió ember haláláért felelős, ezen belül 600 ezer fő azoknak a száma, akik másodlagos dohányfüst-expozíciót (second-hand smoke, SHS) szenvedtek el. A Tobacco Atlas 2018-as számában megjelent jelentés alapján a 15 éves vagy annál idősebb személyek közül világszerte 942 millió férfi és 175 millió nő dohányzott napi rendszerességgel. Magyarországon a dohányzás népegészségügyi és egyben nemzetgazdasági kihívást is jelent. Komoly kockázati tényező a különböző daganatos és krónikus megbetegedések kialakulásának szempontjából; a dohányzás következtében kialakuló betegségek adják a második vezető halálokot. Jelen tanulmányunk célja a Nyíregyháza város életminősége - Háztartáspanel kutatás 2018-as adatbázisára támaszkodva bemutatni a város felnőtt lakosságának dohányzási szokásait.
\end{abstract}

Módszertan: Az adatfelvétel a 2017/2018-as évben történt, az állandó nyíregyházi lakcímmel rendelkező, 18. életévüket betöltött lakosok körében.

Eredmények: A felmérésben résztvevő, Nyíregyházán élő felnőtt lakosság 26,2\%-a rendszeresen dohányzik. Korcsoportos bontásban vizsgálva kitűnik, hogy a rendszeres dohányzók zömét döntően a fiatal és középkorú felnőttek, 18-34 (35,2\%) és a 35-64 évesek $(24,9 \%)$ képezik. A 65 éves vagy ennél idősebb korosztályban alacsonyabb a dohányzók aránya (19,2\%). A környezeti dohányfüst káros hatásai által sújtottak aránya szintén a 18-34 éves korosztályban a legmagasabb, e csoport válaszadóinak 7,9\%-a naponta több mint 5 órát tölt „passzív dohányos" környezetben. Ezen tanulmány alapadatai szerint az alacsonyabb iskolai végzettség és munkanélküliség nem bizonyult veszélyeztető tényezőnek a dohányzás szempontjából.

Következtetések: Céljaink elérésére - a lakosság egészségi állapotának javítására - az alapellátás prevenciós szolgáltatásainak bővítése kedvező hatással lesz. Az egészségfejlesztési programok közül a legjelentősebb változás a dohányzásról leszokni szándékozók támogatásától várható. A vonatkozó egészségügyi szakmai irányelv valamennyi egészségügyi dolgozó számára ajánlásokat fogalmaz meg. Ennek egyik igen fontos eleme a leszokás támogatás gyakorlatának oktatása és fejlesztési lehetőségeinek beillesztése a szakdolgozói képzésekbe.

Kulcsszavak: dohányzási szokások; dohányzásról való leszokás; kockázati csoportok; Nyíregyháza

\section{Summary:}

Introduction: Smoking is responsible for almost 6 million deaths every year worldwide, among which 600,000 individuals had been exposed to SHS (second-hand smoke). According to the report of the Tobacco Atlas, 942 million males, 175 million females (>15yr) smoked on a daily basis in 2018. In Hungary, tobacco use is a public health and a national economic challenge 
also. It is a high-risk factor in the pathogenesis of oncological and chronic diseases. Smokingrelated diseases are the second leading cause of deaths in the country. The aim of this study is to represent the population's (>18yr) smoking habits in Nyíregyháza, based on the data from the research called "Quality of life of Nyíregyháza - Household Panel".

Methods: The survey was conducted in 2017/2018 among residents of Nyíregyháza who were 18 years of age or over.

Results: $26 \%$ of the adult population in Nyíregyháza, represented in the research, is considered regular smoker. Distribution by age groups shows that young and middle aged adults represent the majority of smokers (18-34: 35,2\%, 34-64: 24,9\%). People over the age of 65 are less likely to smoke $(19,2 \%)$. The age group of $18-34$ is also the most likely to be exposed to secondhand smoke, $7,9 \%$ of respondents of this group spend over 5 hours per day in a passive smoker environment. Based on this study we can not conclude that academic background or unemployment are risk factors in terms of smoking.

Conclusion: The development of the primary care's preventive services will have a positive effect on the health status of Nyíregyháza's population. Smoking cessation programs are expected to result in the most significant change, even more so than other health development programs. The relevant health professional guidelines make recommendations for all health workers. In order to achieve the desired outcome, the skills and competencies, required by these plans of actions, need to be embedded in the education of public health professionals.

Keywords: smoking habits; smoking cessation; risk groups; Nyíregyháza

\section{BEVEZETÉS}

A dohányzást az Egészségügyi Világszervezet (World Health Organization, WHO) népegészségügyi katasztrófának nevezi, a betegségek és az idő előtti halálozások legfontosabb megelőzhető okai közé sorolja. Világmértékben a dohányzás évente közel 6 millió ember haláláért felelős. ${ }^{1}$ A Tobacco Atlas 2018-as számában megjelent jelentés alapján a 15 éves vagy annál idősebb személyek közül világszerte 942 millió férfi és 175 millió nő dohányzott napi rendszerességgel. A dohányzás gyakorisága a gazdaságilag fejlett országokban csökkent, de a trend az utóbbi években megtorpanni látszik, viszont a gazdaságilag kevésbé fejlett országokban, mint a Szaharától délre fekvő dél-afrikai országokban az előfordulása egyre fokozódik. ${ }^{2}$ Az Európai Unióban (EU) évente közel 700 ezren veszítik életüket dohányzás okozta megbetegedések következtében. ${ }^{3} \mathrm{Az}$ EU tagországok lakosainak $14 \%$-a csaknem minden nap kénytelen elviselni a mások által teremtett dohányfüstös környezetet. ${ }^{4}$ Magyarországon a dohányzás népegészségügyi és nemzetgazdasági kihívást jelent, ugyanis a kialakuló betegségek miatt jelentős károkat okoz. Komoly kockázati tényező a legkülönbözőbb daganatos és krónikus megbetegedések kialakulásának szempontjából, és a dohány- zás következtében kialakuló betegségek adják a második vezető halálokot. ${ }^{5} \mathrm{Ez}$ azzal együtt is igaz, hogy a halálozás mérsékelt csökkenése érzékelhető, amely óvatosan követi az európai trendet: nők esetében 2014-re a 2005-ös évhez viszonyítva 81\%-ra, férfiaknál pedig 78\%-ra redukálódott. A halálozás gyakoriságában eltűnőben van a két nem közötti különbség. ${ }^{6}$ A dohányzás a népességszaporulat csökkenésében is szerepet játszik: az anya várandósság alatti dohányzása egyike azoknak a megelőzhető és legsúlyosabb kockázati tényezőknek, melyek jelentősen hozzájárulnak a születés előtti, illetve a születés körüli megbetegedéshez és halálozáshoz. ${ }^{7}$ A 2000-es években végzett reprezentatív felmérések alapján, Magyarországon a felnőtt lakosság körében a rendszeres és alkalmi dohányzás együttes gyakorisága 36-38\% körül mozgott. 2010ben a dohányzás miatti közvetlen és közvetett kiadás 450 és 1000 milliárd forint közé esett. ${ }^{8}$ Az 1990-es évek kezdetétől Magyarországon a nemdohányzók védelmében számos jogszabályt vezettek be, amelyek a többi között dohányzóhelyet jelöltek ki a munkahelyeken (1993), tiltották a dohánytermékek reklámozását (1997), és a fiatalkorúak dohánytermékekkel való kiszolgálását. ${ }^{9}$ Miután Magyarország 2004-ben csatlakozott az EU-hoz, a dohánytermékek áfájának lényeges emelésével 
jelentősen növekedtek az ebből származó adóbevételek. Ez 2008-ban 350 milliárd forintra emelkedett, amely a teljes állami költségvetés 4\%-ának felelt meg. ${ }^{10}$ Magyarországon 2012-től nagyon határozott jogi szabályozás lépett hatályba. Minden nyilvános és zárt helyen tilos a dohányzás (éttermek, munkahelyek, egészségügyi és oktatásügyi intézmények), de olyan nyilvános és egyébként nyitott terekben is tilos dohányozni, mint pl. a közösségi közlekedés jármúveinek megállóhelyei vagy a játszóterek. ${ }^{11}$ Reményre adhatnának okot a legutóbbi, 2014-es felmérés adatai, miszerint a rendszeres dohányosok aránya $29 \%$, ami pozitív irányú elmozdulást is jelezhetne a 2009-ben mért 31,4\%-os értékhez viszonyítva, azonban nemenkénti megoszlásban a különbség szembetűnő: a férfiak 34, a nők 22\%-a dohányzik. ${ }^{12}$ Ismert tény, hogy az alacsonyabb gazdasági-társadalmi helyzetű személyek nagyobb valószínűséggel és korábbi életkorban próbálják ki a cigarettát, valamint válnak rendszeres fogyasztóvá, esetükben a leszokást is nehezebb elérni. ${ }^{13}$ Kutatások is alátámasztják, hogy az aktív dohányzás mellett a környezeti dohányfüst-expozíciónak is jelentős szerepe van a hazai kedvezőtlen halálozási és megbetegedési helyzetben. ${ }^{14} \mathrm{~A}$ másodlagos dohányfüstártalom világszerte és évente körülbelül 900 ezer ember haláláért tehető felelőssé. ${ }^{15}$ Az utóbbi években megnövekedett az érdeklődés a harmadlagos dohányzási ártalom hatásai iránt is. Az Amerikai Egyesült Államokban kaliforniai kutatók által végzett vizsgálatok igazolták, hogy a dohányfüstből lerakódott anyagok a levegőben megtalálható salétromsav hatására olyan dohány-specifikus vegyületekké, nitrózaminokká alakulnak át, amelyek a legszélesebb hatásspektrumú és legerősebb rákkeltő anyagok közé tartoznak, viszont a frissen kibocsátott füstben nem találhatók meg. Még kevéssé ismert a harmadlagos dohányfüst-expozíció (third-hand smoke, THS) méhen belüli hatása, de a csecsemőkre és a gyermekekre kifejtett káros hatások vizsgálatáról már számos tanulmány jelent meg. ${ }^{16,17,18,19}$ A dohányzást tiltó rendelkezések megjelenése óta a fejlett társadalmakban a rendszeres dohányzók arányának csökkenése figyelhető meg, azonban ezzel párhuzamosan egy új élvezeti forma, az elektronikus cigaretta (e-cigaretta) használata is megjelent. ${ }^{20} \mathrm{Az}$ e-cigaretta magyarországi elterjedt- sége vélhetően alacsonyabb - hazánkban a felnőtt lakosság 1-4\%-a használja -, szemben az Egyesült Királyságban (5\%), Franciaországban (4\%), és Belgiumban mért (4\%) adatokkal.

Jelen tanulmányunk célja a „Nyíregyháza város életminősége - Háztartáspanel 2018" adatbázisára támaszkodva bemutatni a 18 évnél idősebb felnőtt lakosság dohányzási szokásait felmérő vizsgálatok adatait, elemezni a kialakult helyzetet, valamint a nyíregyházi dohányzási helyzetet a hazai környezettel összevetve elősegíteni a megelőzést és a leszokás támogatás hatékonyságát.

\section{MÓDSZERTAN}

A Nyíregyháza város életminősége - Háztartáspanel kutatás 2008 óta öt hullámban, két-, illetve háromévente mérte fel a városlakók életminőségét. A mintaválasztás módszerét és általános jellemzőinek leírását jelen különszám módszertani bevezetése tárgyalja.' A 2018-as felmérés két szakaszban történt meg. Az első szakaszban, 2017 őszén 541 háztartást értek el, a második szakaszban, 2018 tavaszán pedig 391-et, melyből 389 háztartás válaszai voltak értékelhetők. Az adatfelvétel az állandó nyíregyházi lakcímmel rendelkező, 18. életévüket betöltött lakosok körében történt meg. A minta véletlen kiválasztását a Közigazgatási és Elektronikus Közszolgáltatások Központi Hivatala végezte. ${ }^{21}$

\section{Kategóriák képzése}

Az egy-egy kérdésre adott (egyébként csekély számú) hiányos vagy nem értékelhető válaszok miatt az egyes kategóriák elemszáma eltérhet a vizsgált teljes sokaságtól, ezt azonban minden táblázat címében, illetve celláiban külön feltüntettük. Elemzésünkben vizsgáltuk az életkor szerinti dohányzási szokásokat, amelyek esetében két kategóriát állítottuk szembe a nem dohányzókkal, nevezetesen a naponta, valamint az alkalmanként dohányzókat. Dohányzónak azokat tekintettük, akik a megelőző 30 napban rendszeresen, vagy alkalmanként dohányoztak. Korcsoportok képzésénél az Európai lakossági egészségfelmérés (ELEF) 2014-es kérdőívben használt kategóriákat vettük figyelembe

\footnotetext{
' Takács P, Fábián G, Jávorné Erdei R. A 2018-as Nyíregyháza város életminősége Háztartáspanel kutatás általános és EgészségPanel szakaszainak mintavételi jellemzői. Egészségfejlesztés, LX. évfolyam, Jubileumi lapszám, doi: 10.24365/ef.v60i5.523
} 
(18-34, 35-64, 65 éves vagy annál idősebb). A környezeti dohányfüst-expozíciónak való kitettséget aszerint vizsgáltuk, hogy a megkérdezettek otthonukban vagy ezen kívül szenvednek-e el ártalmat. Vizsgáltuk azt is, hogy a családi állapot milyen hatást gyakorol a dohányzás gyakoriságára.

A statisztikai elemzés céljára az SPSS 20.0 verziójú statisztikai programcsomagot használtuk. A leíró statisztikai számítások során a mintára jellemző és a fentiekben meghatározott változókat mutattuk be. Kereszttáblás elemzéseknél az összefüggések jellemzésére a Pearson-féle khí-négyzet próbát használtuk. 95\%-os megbízhatósági tartomány mellett az eredményeket szignifikánsként értékeltük, ha a p-érték kevesebb, mint 0,05 volt.

\section{EREDMÉNYEK}

A minta jellemzőit az 1. táblázat foglalja össze. A minta nemi megoszlása a következő: 63,2\% nő és $36,8 \%$ férfi. A felmérésben résztvevők 26,2\%-a dohányzik napi rendszerességgel. Az alkalmanként dohányzók aránya 8,7\%. A megkérdezettek 65,1\%-a vallotta magát nem dohányzónak.

1. táblázat: Demográfiai jellemzők és dohányzási szokások a felmérésbe bevont nyíregyházi lakosok körében (n=378)

\begin{tabular}{|c|c|c|}
\hline Változók & $\begin{array}{c}\text { Elemszám } \\
\text { (n) }\end{array}$ & (\%) \\
\hline Nem & 386 & 100,0 \\
\hline Férfi & 142 & 36,8 \\
\hline Nő & 244 & 63,2 \\
\hline Nemzetiség & 386 & 100,0 \\
\hline Roma & 4 & 1,0 \\
\hline Nem-roma & 382 & 99,0 \\
\hline Dohányzási státusz & 383 & 100,0 \\
\hline Naponta dohányzik & 101 & 26,2 \\
\hline Alkalmanként dohányzik & 34 & 8,7 \\
\hline Nem dohányzik & 248 & 65,1 \\
\hline Napi vagy megközelítően napi rendszerességgel legalább egy éven keresztül dohányzott & 343 & 100,0 \\
\hline Igen & 157 & 45,8 \\
\hline Nem & 186 & 54,2 \\
\hline Otthonában tartózkodott olyan helyiségben, ahol mások dohányoztak & 367 & 100,0 \\
\hline Soha, szinte soha & 289 & 78,7 \\
\hline Naponta kevesebb, mint 1 órát & 45 & 12,3 \\
\hline Napi 1-5 órát & 23 & 6,3 \\
\hline Napi több, mint 5 órát & 10 & 2,7 \\
\hline Otthonán kívül olyan helyen tartózkodott, ahol mások dohányoztak & 373 & 100,0 \\
\hline Soha, szinte soha & 231 & 61,9 \\
\hline Naponta kevesebb, mint 1 órát & 87 & 23,3 \\
\hline Napi 1-5 órát & 37 & 9,9 \\
\hline Napi több, mint 5 órát & 18 & 4,8 \\
\hline
\end{tabular}

Forrás: saját szerkesztés 
A különböző korcsoportokban jelentősen eltérnek a dohányzási szokások. Említésre méltó, hogy a naponta dohányzók körében nagyobb arányban vannak a 18-34 év közöttiek, a dohányzók 35,2\%-a ebből a korcsoportból kerül ki. [2. táblázat] Összehasonlítva az ELEF 2014-es felmérés eredményével szembeötlő, hogy az általunk kapott eredmények alacsonyabbak, kivéve a 65 éves vagy annál idősebb korosztályt, de a trend ugyanaz. Eredményeink mutatják - hasonlóan az ELEF 2014 adatához (33,2 \%) -, hogy legtöbben a 18-34 éves korosztályban dohányoznak.

A két nem dohányzási szokásai közötti kismértékű különbség van: a nők 24\%-a dohányzik napi rendszerességgel, szemben a férfiaknál mért 30,5\%kal. [3. táblázat]

Legnagyobb arányban a 18-34 éves korosztály tagjai dohányoztak napi, vagy megközelítően napi rendszerességgel legalább egy éven keresztül. [4. táblázat]

$\mathrm{Az}$ otthonukban dohányfüstnek való kitettségre vonatkozó kérdések alapján elmondható, hogy a korcsoportok tekintetében találunk különbséget, de ez nem szignifikáns. Említést érdemel, hogy elsősorban a 18-34 év közöttiek szenvednek el környezeti dohányfüst-expozíciót. [5. táblázat]

2. táblázat: Dohányzás megoszlása korcsoportok szerint a felmérésbe bevont nyíregyházi lakosok körében (n=368)

\begin{tabular}{|c|c|c|c|}
\hline \multirow[b]{2}{*}{ Korcsoport } & \multicolumn{3}{|c|}{ Dohányzási szokás } \\
\hline & $\begin{array}{c}\text { Igen, naponta } \\
\mathrm{n}(\%)\end{array}$ & $\begin{array}{l}\text { Igen, alkalmanként } \\
\mathrm{n}(\%)\end{array}$ & $\begin{array}{c}\text { Nem } \\
\text { dohányzik } \\
\mathrm{n}(\%)\end{array}$ \\
\hline 18-34 év & $31(35,2)$ & $12(13,6)$ & $45(51,2)$ \\
\hline 35-64 év & $45(24,9)$ & $17(9,4)$ & $119(65,7)$ \\
\hline 65 éves és idősebb & $19(19,2)$ & $3(3,0)$ & $77(77,8)$ \\
\hline Összesen: & $95(25,8)$ & $32(8,7)$ & $241(65,5)$ \\
\hline
\end{tabular}

Forrás: saját szerkesztés

3. táblázat: Dohányzási szokások megoszlása nemek szerint a felmérésbe bevont nyíregyházi lakosok körében (n=383)

\begin{tabular}{|c|c|c|c|}
\hline \multirow[b]{2}{*}{ Nem } & \multicolumn{3}{|c|}{ Dohányzási szokás } \\
\hline & $\begin{array}{c}\text { Igen, naponta } \\
n(\%)\end{array}$ & $\begin{array}{c}\text { Igen, alkalmanként } \\
\mathrm{n}(\%)\end{array}$ & $\begin{array}{l}\text { Nem } \\
\mathrm{n}(\%)\end{array}$ \\
\hline Férfi & $43(30,5)$ & $9(6,4)$ & $89(63,1)$ \\
\hline Nő & $58(24,0)$ & $25(10,3)$ & $159(65,7)$ \\
\hline Összesen: & $101(26,2)$ & $34(8,9)$ & $248(64,6)$ \\
\hline
\end{tabular}

Forrás: saját szerkesztés 
4. táblázat: Napi, vagy megközelitően napi rendszerességgel legalább egy éven keresztül dohányzók megoszlása korcsoport szerint a felmérésbe bevont nyíregyházi lakosok körében (n=333)

\begin{tabular}{|l|c|c|}
\hline Korcsoport & $\begin{array}{c}\text { Igen } \\
n(\%)\end{array}$ & $\begin{array}{c}\text { Nem } \\
n(\%)\end{array}$ \\
\hline $18-34$ év & $46(54,1)$ & $39(45,9)$ \\
\hline 35-64 év & $74(46,0)$ & $87(54,0)$ \\
\hline 65 éves és idősebb & $33(37,9)$ & $54(62,1)$ \\
\hline Összesen: & $153(45,9)$ & $180(54,1)$ \\
\hline
\end{tabular}

Forrás: saját szerkesztés

5. táblázat: Otthonában környezeti dohányfüst-expozíciónak kitettek korcsoport szerinti megoszlása a felmérésbe bevont nyíregyházi lakosok körében ( $n=358)$

\begin{tabular}{|c|c|c|c|c|}
\hline Korcsoport & $\begin{array}{c}\text { Soha, szinte soha } \\
n(\%)\end{array}$ & $\begin{array}{c}\text { Naponta kevesebb, } \\
\text { mint } 1 \text { óra } \\
\text { n (\%) }\end{array}$ & $\begin{array}{c}\text { Napi 1-5 óra } \\
n(\%)\end{array}$ & $\begin{array}{c}\text { Napi több, mint } \\
5 \text { óra } \\
n(\%)\end{array}$ \\
\hline 18-34 év & $63(71,6)$ & $15(17,0)$ & $8(9,1)$ & $2(2,3)$ \\
\hline 35-64 év & $136(79,1)$ & $21(12,2)$ & $9(5,2)$ & $6(3,5)$ \\
\hline 65 éves és idősebb & $86(86,7)$ & $7(7,1)$ & $5(5,1)$ & $1(1,0)$ \\
\hline Összesen: & $284(79,3)$ & $43(12,0)$ & $2(6,1)$ & $9(2,5)$ \\
\hline
\end{tabular}

Forrás: saját szerkesztés

Az otthonukon kívül elszenvedett másodlagos dohányfüstártalom szintén a 18-34 éves korosztályt érinti nagyobb arányban. Napi több mint 5 órát szenvedett el az említett korosztály 7,9\%-a. A 6. táblázatban jól látható, hogy a mintában a 65 éves és ennél idősebb korosztály tagjai soha vagy szinte soha (81\%) nincsenek kitéve környezeti dohányfüstexpozíciónak, akiket másodlagos dohányfüst-expozíciónak ér, jellemzően azok is kevesebb, mint naponta egy órán keresztül tartózkodnak dohányzók közelében (14\%).

A 7. táblázatban látható a mintába bevontak megoszlása dohányzási szokások és a családi állapot összefüggésében. A nem dohányzók között a házasságban élők 73,4\%-os aránya kedvező képet mutat.

Az iskolai végzettség és a dohányzás kapcsolatát vizsgálva elmondható, hogy a nyolc általános iskolai osztállyal vagy annál kevesebb, valamint a szakmunkás végzettséggel rendelkezők esetében nagyobb arányban találunk napi rendszerességgel dohányzókat. [8. táblázat]

A naponta dohányzók $67,3 \%$-a rendelkezik munkaviszonnyal. Az alkalmanként dohányzók is nagyobb arányban azok közül kerülnek ki, akik jelen vannak a munkaerőpiacon. [9. táblázat] 
6. táblázat: Otthonán kívül környezeti dohányfüst-expozíciónak kitettek korcsoport szerinti megoszlása a felmérésbe bevont nyíregyházi lakosok körében $(n=364)$

\begin{tabular}{|c|c|c|c|c|}
\hline Korcsoport & $\begin{array}{c}\text { Soha, szinte soha } \\
n(\%)\end{array}$ & $\begin{array}{l}\text { Naponta kevesebb, } \\
\text { mint } 1 \text { óra } \\
n(\%)\end{array}$ & $\begin{array}{c}\text { Napi 1-5 óra } \\
n(\%)\end{array}$ & $\begin{array}{c}\text { Napi több, mint } \\
5 \text { óra } \\
n(\%)\end{array}$ \\
\hline 18-34 év & $35(39,3)$ & $29(32,6)$ & $18(20,2)$ & $7(7,9)$ \\
\hline 35-64 év & $111(63,4)$ & $43(24,6)$ & $11(6,3)$ & $10(5,7)$ \\
\hline 65 éves és idősebb & $81(81,0)$ & $14(14,0)$ & $5(5,0)$ & $0(0,0)$ \\
\hline Összesen: & $227(62,4)$ & $86(23,6)$ & $34(9,3)$ & $17(4,7)$ \\
\hline
\end{tabular}

Forrás: saját szerkesztés

7. táblázat: A felmérésbe bevont nyíregyházi lakosok megoszlása dohányzási szokások és családi állapot szerint (n=365)

\begin{tabular}{|c|c|c|c|c|c|c|}
\hline Dohányzási szokás & $\begin{array}{c}\text { Nőtlen/ } \\
\text { Hajadon } \\
\text { n (\%) }\end{array}$ & $\begin{array}{l}\text { Házas } \\
\text { n (\%) }\end{array}$ & $\begin{array}{c}\text { Élettárs } \\
\text { n (\%) }\end{array}$ & $\begin{array}{l}\text { Elvált } \\
\text { n (\%) }\end{array}$ & $\begin{array}{c}\text { Özvegy } \\
n(\%)\end{array}$ & Összesen \\
\hline Naponta & $27(39,7)$ & $36(18,8)$ & $18(32,7)$ & $11(30,6)$ & $4(28,6)$ & $96(26,3)$ \\
\hline Alkalmanként & $6(8,8)$ & $15(7,8)$ & $7(12,7)$ & $3(8,3)$ & $1(7,1)$ & $32(8,8)$ \\
\hline Nem dohányzik & $35(51,5)$ & $141(73,4)$ & $30(54,5)$ & $22(61,1)$ & $9(64,3)$ & $237(64,9)$ \\
\hline
\end{tabular}

Forrás: saját szerkesztés

8. táblázat: A dohányzási szokások megoszlása iskolai végzettség szerint a felmérésbe bevont nyíregyházi lakosok körében (n=363)

\begin{tabular}{|c|c|c|c|c|c|c|c|c|c|}
\hline $\begin{array}{l}\text { Dohányzási } \\
\text { szokás }\end{array}$ & $\begin{array}{c}\leq 8 \text { általános } \\
\text { iskolai osztály } \\
\mathrm{n}(\%)\end{array}$ & $\begin{array}{c}\text { Szakiskola } \\
\text { n (\%) }\end{array}$ & $\begin{array}{l}\text { Szakközép- } \\
\text { iskola } \\
\text { n (\%) }\end{array}$ & $\begin{array}{c}\text { Gimnázium } \\
\text { n (\%) }\end{array}$ & $\begin{array}{l}\text { OKJ } \\
\text { n (\%) }\end{array}$ & $\begin{array}{c}\text { Fóiskola/ } \\
\text { BSc vagy } \\
\text { BA } \\
\text { n (\%) }\end{array}$ & $\begin{array}{c}\text { Egyetem/ } \\
\text { MSc vagy } \\
\text { MA } \\
\text { n (\%) }\end{array}$ & $\begin{array}{l}\mathrm{PhD} \\
\mathrm{n}(\%)\end{array}$ & $\begin{array}{c}\text { Összesen } \\
n(\%)\end{array}$ \\
\hline Naponta & $\begin{array}{c}9 \\
(31,0)\end{array}$ & $\begin{array}{c}19 \\
(33,9)\end{array}$ & $\begin{array}{c}15 \\
(30,0)\end{array}$ & $\begin{array}{c}17 \\
(30,4)\end{array}$ & $\begin{array}{c}15 \\
(26,8)\end{array}$ & $\begin{array}{c}10 \\
(14,1)\end{array}$ & $\begin{array}{c}10 \\
(29,4)\end{array}$ & $\begin{array}{c}0 \\
(0,0)\end{array}$ & $\begin{array}{c}95 \\
(26,1)\end{array}$ \\
\hline $\begin{array}{l}\text { Alkalman- } \\
\text { ként }\end{array}$ & $\begin{array}{c}0 \\
(0,0)\end{array}$ & $\begin{array}{c}4 \\
(7,2)\end{array}$ & $\begin{array}{c}3 \\
(6,0)\end{array}$ & $\begin{array}{c}4 \\
(7,1)\end{array}$ & $\begin{array}{c}4 \\
(7,1)\end{array}$ & $\begin{array}{c}7 \\
(9,9)\end{array}$ & $\begin{array}{c}7 \\
(20,6)\end{array}$ & $\begin{array}{c}1 \\
(14,3)\end{array}$ & $\begin{array}{c}30 \\
(8,3)\end{array}$ \\
\hline $\begin{array}{l}\text { Nem } \\
\text { dohányzik }\end{array}$ & $\begin{array}{c}24 \\
(69,0)\end{array}$ & $\begin{array}{c}33 \\
(58,9)\end{array}$ & $\begin{array}{c}32 \\
(64,0)\end{array}$ & $\begin{array}{c}35 \\
(62,5)\end{array}$ & $\begin{array}{c}37 \\
(66,1)\end{array}$ & $\begin{array}{c}54 \\
(76,1)\end{array}$ & $\begin{array}{c}17 \\
(50,0)\end{array}$ & $\begin{array}{c}6 \\
(85,7)\end{array}$ & $\begin{array}{c}238 \\
(65,6)\end{array}$ \\
\hline
\end{tabular}

Forrás: saját szerkesztés

9. táblázat: Dohányzási szokások megoszlása munkaviszony szerint a felmérésbe bevont nyíregyházi lakosság körében (n=372)

\begin{tabular}{|c|c|c|}
\hline Dohányzási szokások & $\begin{array}{c}\text { Munkaviszonnyal rendelkezik } \\
\mathrm{n}(\%)\end{array}$ & $\begin{array}{c}\text { Munkaviszonnyal nem rendelkezik } \\
\mathrm{n}(\%)\end{array}$ \\
\hline Naponta dohányzik & $66(67,3)$ & $32(32,7)$ \\
\hline Alkalmanként & $23(69,7)$ & $10(30,3)$ \\
\hline Nem dohányzik & $130(53,9)$ & $111(46,1)$ \\
\hline Összesen: & $219(58,9)$ & $153(41,1)$ \\
\hline
\end{tabular}

Forrás: saját szerkesztés 


\section{MEGBESZÉLÉS ÉS KÖVETKEZTETÉSEK}

Eredményeink szerint a válaszadók 26,2\%-a dohányzik rendszeresen. Azok aránya, akik nem dohányoztak $65,1 \%$, az alkalmi dohányosok gyakorisága pedig 8,7\% volt. Az ELEF 2014 eredményei szerint a magyar felnőtt lakosság 27,5\%-a gyújtott rá napi rendszerességgel. ${ }^{12}$ Ezzel összehasonlítva az általunk mért eredmények hasonló képet mutatnak. A 2014. évi Eurobarometer felmérés adataihoz viszonyítva - ahol is a lakosság 26\%-a dohányzó (ide értve a cigaretta-, szivar-, szivarka-, pipahasználókat, de az e-cigarettát szívók nincsenek benne ebben a kategóriában) közel azonos. ${ }^{3}$

A két nem dohányzási szokásai közötti kismértékú különbséget találtunk, az általunk megkérdezettek közül a nők 24\%-a dohányzik napi rendszerességgel szemben a férfiaknál mért 30,5\%-kal. Ezt összehasonlítva az ELEF 2014-es felmérés eredményével miszerint a nők 22,2\%-a és a férfiak 33,5\%-a dohányzott napi rendszerességgel - láthatjuk, hogy az értékek közel azonosak.

A dohányfüstnek való kitettségre és a passzív dohányzásra vonatkozó kérdések alapján kiderült, hogy az általunk vizsgált korcsoportok között különbség mutatkozik, ám erre vonatkozóan nem találtunk szignifikáns összefüggést. Említést érdemel, hogy leginkább a 18-34 év közöttiek szenvednek el környezeti dohányfüst-expozíciót. Az ELEF eredményei alapján elmondható, hogy 2014-ben a megkérdezettek $6 \%$-a napi több mint egy órát volt dohányfüstös környezetben, és ez közel azonos az általunk Nyíregyházán mért 6,1\%-os eredménnyel. Országosan kevesebb, mint egy órás dohányfüstexpozíciónak való kitettség a lakosság 2,2\%-ra volt jellemző, szemben a nyíregyházi minta 12\%-ával. Az ELEF 2014-ben résztvevők 84,5\%-a egyáltalán nem volt kitéve otthonában dohányfüst-expozíciónak, ami a mi kutatásunkban alacsonyabb mértékú volt: $79,3 \%$.

Az otthonán kívül elszenvedett másodlagos dohányfüstártalom szintén a 18-34 éves korosztályt érinti nagyobb arányban, így napi több mint 5 órát szenved el a válaszadók 7,9\%-a. A 65 éves és idősebb korosztály ilyen hosszú ideig egyáltalán nincs kitéve ennek az ártalomnak. Az eredmények alapján megállapítható, hogy szignifikáns összefüggés van az életkor, valamint az otthonon kívüli környezetben elszenvedett dohányfüst-expozíció között. A felmé- résben résztvevők 9,3\%-a napi több mint egy órát, ennél kevesebb ideig a lakosság 23,6\%-a volt kitéve passzív dohányzásnak. Az ELEF 2014 adatai szerint országos szinten a lakosság 2,3\%-a napi több mint egy órát, 1,7\%-a kevesebb, mint egy órát volt kitéve dohányfüst-expozíciónak, míg 80,3\%-uk egyáltalán nem töltött időt dohányfüstös környezetben. ${ }^{12}$ Ennek alapján kijelenthetjük, hogy Nyíregyházán az országosnál kedvezőtlenebb a helyzet.

Az általunk végzett felmérés korcsoportos adataiból az is kitúnik, hogy a rendszeres dohányosok zömmel a 18-34 (35,2\%) és a 35-64 éves (24,9\%) korosztályból kerülnek ki. A 65 éves vagy afeletti korosztályban alacsonyabb a dohányzók aránya (19,2\%). A napi rendszerességgel dohányzók között az egyedülállók 39,7\%-os értéke igen kedvezőtlen képet ad. A nem dohányzók esetében megállapítható, hogy a gyakoriság nagyobb a házasságban élók esetében. Ennek 73,4\%-os aránya igen kedvezőnek ítélendő. A nyolc általános iskolai osztállyal vagy annál kevesebbel, valamint a szakmunkás végzettséggel rendelkezők esetében nagyobb arányban találunk napi rendszerességgel dohányzókat (31,0-33,9\%). A munkaviszony nem bizonyult protektív tényezőnek, mert a foglalkoztatottak nagyobb arányban dohányoznak szemben azokkal, akik nem rendelkeznek munkaviszonnyal.

A WHO egyik kiemelkedő feladata az utóbbi évtizedekben a dohányzás elleni küzdelem, amelynek célja a felnőtt lakosság körében $20 \%$ alá csökkenteni a dohányzók arányát. Ennek érdekében jött létre a Dohányzás-ellenőrzési Keretegyezmény, és az EU tagállamai is a legszigorúbb intézkedéseket alkalmazzák a dohányzás visszaszorítása érdekében. ${ }^{22,23}$ A cél elérése érdekében az oktatás területén a dohányzás prevenciónak állandóan jelen kell lennie. Számos, a dohányzás abbahagyását segítő program múködik a világon, melyek egyéni vagy csoportos segítséget nyújtanak, illetve elektronikus szolgáltatásokon keresztül segítik a leszokni vágyókat. ${ }^{24,25}$ $\mathrm{Az}$ Országos Korányi Pulmonológiai Intézetben 2012-ben kezdte meg működését a Dohányzás Leszokást Támogató Módszertani Központ azzal a céllal, hogy megbízható adatok ismeretében a hazai dohányzási szokások körvonalazódása alapján szakmai segítséget nyújtson a leszokást támogató programok megvalósításához. Ezzel egy időben a tüdőgondozókban elindult az egyéni, valamint csoportos dohányzás leszokást támogató tanácsadás. ${ }^{26}$ 
A dohányzás egészségre gyakorolt káros hatásai a fiatalokat és az alacsony iskolai végzettségűeket feltételezhetően a hiányos ismereteik miatt - különösen veszélyeztetik. ${ }^{27,28} \mathrm{Az}$ eddigi kutatások is ezt támasztják alá, ezzel szemben a saját eredményeink birtokában elmondhatjuk, hogy a magasabb iskolai végzettséggel rendelkezőket sem szabad figyelmen kívül hagyni, mert közöttük nagyon magas a rendszeres, napi cigarettázók aránya. ${ }^{26,29}$

Mindenképpen fontos, hogy a leszokás támogatása a legszélesebb körben ismertté váljon, mivel ez a program hatékonyságának és sikerességének alapvető feltétele. ${ }^{30}$

A felsőoktatásban és ezen belül az egészségtudományi képzéseken tanuló hallgatók számára a dohányzás prevenciós tevékenységnek állandóan jelen kell lennie. ${ }^{31,32}$ Általános céljaink elérésére az alapellátás prevenciós szolgáltatásainak bővítése, a lakosság egészségi állapotának javitása remélhetőleg kedvező hatással lesz. Az egészségfejlesztési programok közül a legjelentősebb változás a dohányzásról való leszokás támogatásától várható. ${ }^{33}$ A vonatkozó egészségügyi szakmai irányelv valamennyi egészségügyi dolgozó számára ajánlást fogalmaz meg. Ennek egyik igen fontos eleme, hogy a leszokástámogatás gyakorlatának oktatását és fejlesztési lehetőségeit integrálja a szakdolgozói képzésekbe.

Ki kell emelni, hogy a védőnő, mint az alapellátás szakembere, a dohányzásleszokás támogatása során képes minimál intervencióra, a nemzetközi gyakorlatban javasolt, igen elterjedt „5 $\mathrm{A}$ ” módszer lépéseinek követésével. ${ }^{34}$ Ebből kiindulva 2018-ban a „Kelet-európai Ápolók Kiválósági Központja a Dohányzás Visszaszorításáért" program keretében
Szabolcs-Szatmár-Bereg megyében 45 védőnő vett részt területi képzésben. A képzés célja a leszokástámogatás gyakorlatának megismertetése a védőnőkkel, akik munkájuk során ennek hatékony végzésére kompetensé válnak, valamint felkeltik és erősítik a várandós és gyermekágyas anyák leszokás iránti motivációját. ${ }^{35}$ Nyíregyházán 2019. június 7-én egyedülálló módon dohányzásról leszokást támogató tanácsadás nyílt. A dohányzó várandósok kiszűrése egyszerűsített kérdőíves adatrögzítéssel történik az egyes védőnői körzetekben, a védőnők javasolják az érintett várandósoknak, hogy vegyenek részt a leszokást támogató programban. Erre az Egészségügyi Alapellátás Igazgatóság épületében múködő „Dohányzásról való leszokást támogató tanácsadáson" van lehetőség, ahol is erre képzett tanácsadó nyújt segítséget a dohányzásról leszokni akaró várandósoknak. ${ }^{36,37}$

A felmérésünk eredményeiből levont következtetések csak a kutatásban résztvevőkre érvényesek, így nem vonatkoztathatók Nyíregyháza teljes lakosságára. A mintába csekély számú roma nemzetiségú került be, ezért roma és nem-roma alcsoportonként történő elemzést nem tudtuk végezni. A Nyíregyháza város életminősége - Háztartáspanel kutatás reprezentatív mintaválasztását feltételezve ez azt jelenti, hogy vagy Nyíregyháza lakosságának 1\%-a roma, vagy az 541 háztartásból a 150 nem válaszoló között a romák halmozottan fordultak elő. Továbbá a mintában a nők felülreprezentáltak voltak. Ugyanakkor fontos kiemelni, hogy a jelenlegi kutatási adatok szerint a nemek szerinti, valamint a nemzetiségi hovatartozás nem közömbös a dohányzás szempontjából. ${ }^{13}$

\section{HIVATKOZÁSOK}

\footnotetext{
${ }^{1}$ World Health Organization. Report on the global tobaccoepidemic, Enforcing bans on tobacco advertising, promotion and sponsorship 2013; 16. https://apps.who.int/iris/bitstream/handle/10665/85380/9789241505871 eng.pdf;jsessionid=BCF3C6DF10103AF14B14FBC72B06F437?sequence=1 (Elérve: 2019. 09. 02.)

2 Drope J, Schluger N, Cahn Z, Drope J, Hamill S, Islami F, Liber A, Nargis N, Stoklosa M. The Tobacco Atlas. 6th ed. 2018. Atlanta: American Cancer Society and Vital Strategies. https://tobaccoatlas.org/ (Elérve: 2019. 11. 12.)

${ }^{3}$ Special Eurobarometer 429. Attitudes of Europeans towards tobacco and electronic cigarettes European Commission, Brussels, 2015. https://ec.europa.eu/commfrontoffice/publicopinion/archives/ebs/ebs 429 en.pdf

(Elérve: 2019. 11. 12. )

${ }^{4}$ Flash Eurobarometer 253 Survey on Tobacco. Analytical report. European Commission, Brussels 2009.

https://ec.europa.eu/commfrontoffice/publicopinion/flash/fl 253 en.pdf (Elérve: 2019. 11. 12.)
} 
${ }^{5}$ Pénzes M, Balázs P. Dohányzásellenes intézkedések hatékonyságának megítélése serdülők körében. Egészségtudomány. 2013; 57(1): 57-74. http://egeszsegtudomany.higienikus.hu/cikk/2013-1/2013-1.pdf (Elérve: 2019. 11. 14.)

${ }^{6}$ Varsányi P. (szerk.): Egészségjelentés 2016: Információk a népegészségügyi beavatkozások célterületeinek azonosításához a nem fertőző betegségek és az egészségmagatartási mutatók elemzése alapján. Nemzeti Egészségfejlesztési Intézet, Budapest, 2017. https://konyvtar.aeek.hu/cgi-bin/egyszeru4.exe?a1=0\&a2=0\&a3=1\&a4=10\&a5=M\&a6=e251 (Elérve: 2019. 12. 10.)

${ }^{7}$ Rákóczi I, Fogarasi-Grenczer A, Balázs P. A várandósság alatt dohányzó nők szocio-ökonómiai hátterének jelentősége a leszokás támogatásában. Védőnő. 2014; 24(4): 28-31.

${ }^{8}$ Demjén T, Kiss J, Formanek-Balku E. Az Egészségügyi Világszervezet Nemzetközi Ifjúsági Dohányzás Felmérésének 2016. évi hazai megvalósításáról. Zárótanulmány, Budapest 2016. október.

https://www.fokuszpont.dohanyzasvisszaszoritasa.hu/sites/default/files/01 GYTS 2016 osszefoglalo tanulmany.pdf (Elérve: 2019. 11. 14.)

${ }^{9}$ Paulik E. Social determinants of smoking and quitting in Hungary. In: Increasing Capacity for Tobacco Research in Hungary 2008-2013. Institute for History of Hungarian Sciences, Budapest, 2013; 39-60.

https://mafiadoc.com/increasing-capacity-for-tobacco-research-in 5c58bb7b097c47a4388b45d0.html

(Elérve: 2019. 12. 10.)

10 Bodrogi J. Economic impact of tobacco smoking. In: Increasing Capacity for Tobacco Research in Hungary 2008-2013. Budapest, Institute for History of Hungarian Sciences Budapest, 2013; 185-214. https://mafiadoc.com/increasingcapacity-for-tobacco-research-in_5c58bb7b097c47a4388b45d0.html (Elérve: 2019. 12. 10.)

11 2011. évi XLI. törvény a nemdohányzók védelméről és a dohánytermékek fogyasztásának, forgalmazásának egyes szabályairól szóló 1999. évi XLII. törvény módosításáról. https://mkogy.jogtar.hu/jogszabaly?docid=a1100041.TV (Elérve: 2019. 09. 15.)

12 Központi Statisztikai Hivatal. Európai lakossági egészségfelmérés, 2014. Statisztikai Tükör 2015/29., https://www.ksh.hu/docs/hun/xftp/stattukor/elef14.pdf (Elérve: 2019. 12. 10.)

${ }^{13}$ Paulik E, Lukács A, Rogers, T, Easterling D, et al. Dohányzási szokások és dohányzással kapcsolatos ismeretek a roma népesség körében. Népegészségügy 2012; 90 4. 246-252.

${ }^{14}$ Balku E, Varsányi P. Dohányzás okozta megbetegedés és halálozás. In: Demjén T. (szerk.) Dohányzás visszaszorítása 2016. Dohányzás Fókuszpont, Nemzeti Egészségfejlesztési Intézet. Budapest, 2016

${ }^{15}$ Kovács G, Manchin R. A passzív dohányzás hatása az egészségre. In: Dohányzás vagy egészséges életmód? Medicina Könyvkiadó Zrt. Budapest 2006; 161-162.

${ }^{16}$ Hrubá D, Šikolová V. Co je „third-hand smoke“?. General Practitioner/Prakticky Lekar [serial online]. April 2014;94(4):190-194. https://www.prolekare.cz/en/journals/general-practitioner/2014-4/what-is-third-hand-smoke49738 (Elérve: 2019. 12. 10.)

${ }^{17}$ Ferrante G, Simoni M, Cibella F, Ferrara F, Liotta G, Malizia V, Corsello G, Viegi G, La Grutta S. Third-hand smoke exposure and health hazards in children. Monaldi Arch For Chest Dis. 2013;79(1):38-43. doi: 10.4081/monaldi.2013.108

${ }^{18}$ Sleiman M, Gundel LA, Pankow JF, Jacob P 3rd, Singer BC, Destaillats H. Formation of carcinogens indoors by surfacemediated reactions of nicotine with nitrous acid, leading to potential thirdhand smoke hazards. Proc Natl Acad Sci U S A. 2010;107(15):6576-81. doi: 10.1073/pnas.0912820107

19 Jacob P 3rd, Benowitz NL, Destaillats H, et al. Thirdhand Smoke: New Evidence, Challenges, and Future Directions. Chem Res Toxicol. 2017;30 (1):270-294. doi: 10.1021/acs.chemrestox.6b00343

${ }^{20}$ Cselkó Zs, Pénzes M. Az elektronikus cigarettáról meglévő ismeretek összefoglalása. Orv Hetil., 2016; 157(25), 979-986. doi: 10.1556/650.2016.30469

21 Jávorné Erdei R, Takács P. Szubjektív egészségi állapot és annak változásai Nyíregyházán. Acta MedSoc 2018; 9.26. (3-15) doi: 10.19055/ams.2018.9/27/7

22 WHO Framework Convention on Tobacco Control. WHO, 2003.

https://apps.who.int/iris/bitstream/handle/10665/42811/9241591013.pdf;jsessionid=080A4AB27FBECE428A234CA7E3FAF6D1? sequence=1 (Elérve 2019. 12. 09.)

${ }^{23}$ WHO global report on trends in prevalence of tobacco smoking. WHO, 2015. http://apps.who.int/iris/bitstream/10665/156262/1/9789241564922 eng.pdf?ua=1 (Elérve: 2019. 12. 10.)

${ }^{24}$ McCrabb S, Balogh Z, Baker AL, et al. Development of an online smoking cessation program for use in hospital and following discharge: smoke-free recovery. BMJ Innovations. 2017;3:115-122. doi: 10.1136/bmjinnov-2016-000126 ${ }^{25}$ WHO Regional Office for Europe. European Tobacco use. Trends Report 2019. WHO, 2019.

http://www.euro.who.int/ data/assets/pdf file/0009/402777/Tobacco-Trends-Report-ENG-WEB.pdf?ua=1

(Elérve: 2019. 12. 10.)

${ }^{26}$ Cselkó Zs, Kovács G. Dohányzási szokások Magyarországon: az utóbbi évtized felméréseinek elemzése. Orv Hetil., 2013; 154 (37): 1454-1468. doi: 10.1556/OH.2013.29694 
27 Paulik E, Rogers T, Easterling D, Nagymajtényi I. A dohányzással kapcsolatos ismeretek és attitűdök egyenlőtlenségei Magyarországon. Egészségtudomány, 2012; 56 (3): 8-24 http://egeszsegtudomany.higienikus.hu/cikk/2012-3/20123.pdf (Elérve: 2019. 12. 10.)

${ }^{28}$ WHO global report on trends in prevalence of tobacco smoking 2015. http://apps.who.int/iris/bitstream/10665/156262/1/9789241564922 eng.pdf?ua=1 (Elérés: 2019. 10. 12.)

${ }_{29}$ Pénzes M, Foley LK, Balázs P, Urbán R. Patterns Of Alternative Tobacco Product Experimentation Among Ever Smoker Adolescents. Cent Eur J Public Health 2019; 27 (1): 3-9. doi: 10.21101/cejph.a5364 (Elérés: 2019. 12. 10.)

${ }^{30}$ Zhuang YL, Gamst AC, Cummins SE, Wolfson T, Zhu SH. Comparison of smoking cessation between education groups: findings from 2 US National Surveys over 2 decades. Am J Public Health. 2015;105(2): 373-9. doi:

10.2105/AJPH.2014.302222

${ }^{31}$ Ward KD. Tobacco intervention research in low- and middle-income countries: lessons learned and future directions. J Smok Cessat. 2016; 11(2): 61-64. doi: 10.1017/jsc.2016.6

32 Urbán R. Lehetnek-e az elvárások a dohányzás prevenció célpontjai? A dohányzással kapcsolatos elvárások szerepe a serdülökori dohányzásban. Egészségtudomány, 2011; 55(2): 105. http://egeszsegtudomany.higienikus.hu/cikk/20112/2011-2.pdf (Elérve: 2019. 12. 09.)

${ }_{33}$ Balázs P, Fogarasi-Grenczer A, Rákóczi I, Kristie LF. A koraszülés epidemiológiája Északkelet-Magyarországon. Gyermekgyógyászat 2015; 66(3): 166-172.

${ }^{34}$ Az Emberi Erőforrások Minisztériuma egészségügyi szakmai irányelve a dohányzásról való leszokás támogatásáról. 2019. EüK. 2. szám EMMI szakmai irányelv 1. https://www.hbcs.hu/uploads/jogszabaly/2837/fajlok/EMMI_szakmai iranyelve dohanyzasrol.pdf (Elérve: 2019. 12. 09.)

${ }^{35}$ Cselkó Zs, Pataki E, Fényes M, Várfalvi M, Rákóczi I, Vecsernyés E, Forgó A, Csányi P. Smoking cessation training for health visitors in Hungary. Tob. Prev. Cessation 2019;5 (Supplement):A19 doi: 10.18332/tpc/105316

${ }^{36}$ Várandósan már nemcsak maguknak ártanak. SZON, 2019. 07. 05. https://szon.hu/eletstilus/helyi-eletstilus/varandosan-mar-nem-csak-maguknak-artanak-3172169/(Elérve: 2019. 12. 10.)

${ }^{37}$ Országosan 15, megyénkben 20 százaléka dohányzik a várandós kismamáknak. Frissmédia, 2019. 07. 05. https://frissmedia.hu/hir/orszagosan-15-megyenkben-20-szazaleka-dohanyzik-a-varandos-kismamaknak/11438 (Elérve: 2019. 12. 10.) 